\title{
Ethnobotanic study of Randia aculeata (Rubiaceae) in Jamapa, Veracruz, Mexico, and its anti-snake venom effects on mouse tissue
}

Gallardo-Casas CA (1, 2), Guevara-Balcázar G (1), Morales-Ramos E (2), Tadeo-Jiménez Y (2), Gutiérrez-Flores O (2), Jiménez-Sánchez N (2), Valadez-Omaña MT (2), Valenzuela-Vargas MT (3), Castillo-Hernández MC (1)

(1) Section of Graduate Studies and Research, Higher School of Medicine, National Polytechnic Institute, Mexico City, Mexico; (2) Department of Research and Biology, Center of Scientific and Technological Studies 6 "Miguel Othón de Mendizábal", National Polytechnic Institute, Mexico City, Mexico; (3) Department of Morphology, National School of Biological Sciences, National Polytechnic Institute, Mexico City, Mexico.

\begin{abstract}
In Mexico, medicinal plants are widely used. The use of Randia aculeata by healers against snakebites has never been scientifically tested in relation to possible effects on blood parameters and muscle tissue damage. Interviews were carried out in Jamapa, Veracuz, Mexico, with local residents to collect information about the traditional use of Randia aculeata. In this locality, seven pieces of fruit from the plant are mixed in a liter of alcohol, and then administered orally against snakebites. By using histological techniques and a murine model, we explored its cytoprotective properties against the effects of Crotalus simus and Bothrops asper venoms. Possible protections provided by the plant against tissue damage to skeletal and cardiac muscles and against the typical loss of red blood cells were analyzed. Randia aculeata caused an increase in microhematocrit and total hemoglobin, parameters that are often decremented in association with the loss of red blood cells, which is a characteristic effect of animal venom. Randia aculeata was also shown to protect against the lowering of platelet levels caused by Bothrops asper venom. Finally, Randia aculeata produced a partial inhibition of necrosis following administration of snake venom in skeletal and myocardial muscles. The present results provide solid evidence for the traditional use of Randia aculeata against snakebites, as demonstrated by protection against muscular tissue damage and the diminution of red blood cells.
\end{abstract}

Key words: Rubiaceae, antivenoms, Bothrops, Crotalus, cytoprotection.

\section{INTRODUCTION}

Ophidian accidents represent a serious health problem, as they lead to an estimated 50,000 deaths and another 22,000 permanent injuries, including amputations and other losses of bodily functions that impede proper development within society (1). Among medical treatments for such accidents, medicinal plants used as ophidian antidotes generate special interest because of their potential pharmacological use. However, information remains scarce and many cases have not been subjected to true scientific analysis.

In Mexico, a few plants have been evaluated including Brongniartia podalyrioides and $B$. intermedia, which were found to contain edunol, a substance that neutralizes the cardiological and toxic effects of the Bothrops atrox venom (2). In the country there are snakebite healers called "culebreros" that claim to know the proper antiophidic herbal remedies and methods of application (3). These healers often represent the only alternative given the lack of medical services that could otherwise provide anti-ophidian serum based on scientific research. In the best of cases, such a healer is apprenticed based on generations of practice that has led to an accumulation of knowledge on the effectiveness of distinct medicinal plants. A healer with this background is in reality keeping a valuable tradition alive (4). However, information on this use of medicinal plants is scarce and in many cases lacks scientific analysis. 
Veracruz ranks second among Mexican states in the number of snakebite accidents. Species confirmed in these cases are Bothrops asper (48\%) followed by Crotalus simus (5). One of the towns in Veracruz that has maintained the tradition of snakebite healers is Acayucan, where different plants are used for this purpose. One of these plants is Randia aculeata (crucetillo). The popular use of this particular plant has spread to Jamapa, a town in central Veracruz dedicated mainly to agriculture and farming, where local people prepare, without consulting a snakebite healer, an alcoholic beverage made from the fruit of this plant, which they drink when they (or even their pets) are bitten by a snake.

The aim of the present study was to make an ethnobotanical study of Randia aculeata (Rubiaceae), and test the plant under laboratory conditions in order to confirm or negate the validity of its active ingredients as well as its usual method of administration, by analyzing its effects on skeletal muscle, heart and blood in a murine model.

\section{MATERIALS AND METHODS}

\section{Ethnobotanical Study}

We followed the methodology created by Vázquez-Ramírez et al. (6). One hundred questionnaires were applied in the municipality of Jamapa, Veracruz, Mexico. While the interviews were taking place with the local people, we always showed them a specimen of the plant to avoid confusion. We visited the homes and businesses of residents and interviewed people that were willing to answer our questions. The questionnaire can be seen in Figure 1.

\section{Preparation of Plants}

The plants, collected in rural communities in Jamapa, Veracruz, Mexico, were identified by a specialist in medicinal plants, Abigail AguilarContreras, as Randia aculeata. A specimen of this species was deposited in the Herbarium of Medicinal Plants at the Centro Medico Siglo XXI hospital, and was registered as a plant for traditional medical use. The plant was prepared in the traditional manner where seven complete pieces of fruit were chopped up and left immersed in $1 \mathrm{~L}$ of sherry wine for one week (7).

\section{Venom}

Venoms from Crotalus simus and Bothrops asper were kindly donated by Edgar Reina-Ponce and Orlando Reina-Ponce, directors of Museo Viviente Veracruz Salvaje in Veracruz, Mexico. The quantification of proteins in the venom was performed by means of the Bradford method (8),

\section{QUESTIONNARIE APPLIED}

\section{NAME}

\section{Type of interviewee:}

( ) Shamman

\section{( ) Stallholder \\ ( ) Informant}

\section{SEX: F（） M( )}

¿What is the plant's name?

Part of the plant used
Fruit ( )
Flower( ) Leaves ( )
Root () Stem ()
All of the plant ( )

Mention the disease(s) you use the plant against

Mixed with other plants?

How do you prepare the plant?

Method of administration

Quantity and frequency of use

Date:

Questionnaire number

Figure 1. Applied questionnaire in Jamapa, Veracruz. 
and after that the $\mathrm{LD}_{50}$ was determined by the Lorke method (9).

\section{Animals}

Thirty-eight male CD1 mice (20-25 g) were used. They were maintained in groups of six or eight in a Plexiglas cage, with food and water provided ad libitum in a room with constant temperature $\left(21 \pm 2^{\circ} \mathrm{C}\right)$ and a 12-hour light/ dark cycle (lights on at $8 \mathrm{am}$ ). All experimental procedures described in this study are in accordance with the guidelines established by the Secretary of Health in the Seventh Title of the Regulations of the General Law of Health Regarding Health Research and the Mexican Official Standard NOM-062-ZOO-1999, which stipulates technical specifications for production, care, and use of laboratory animals.

The animals were randomly assigned to six groups, including a control group that received $0.9 \%$ saline administered by intragastric (IG) route and $0.9 \%$ saline administered by intramuscular (IM) route $(n=6)$, and five experimental groups that received:

1. R. aculeata IG $+0.9 \%$ saline IM $(n=6)$,

2. $0.9 \%$ saline $\mathrm{IG}+1 \mathrm{mg} / \mathrm{kg}$ B. asper venom IM $(n=8)$,

3. R. aculeata $\mathrm{IG}+1 \mathrm{mg} / \mathrm{kg}$ B. asper venom IM

$$
(n=8) \text {, }
$$

4. $0.9 \%$ saline $\mathrm{IG}+5 \mathrm{mg} / \mathrm{kg}$ C. simus venom IM $(n=8)$,

5. R. aculeata $\mathrm{IG}+5 \mathrm{mg} / \mathrm{kg}$ C. simus venom IM $(n=8)$.

The administration of saline or R. aculeata 10 $\mathrm{mL} / \mathrm{kg}$ IG was made immediately before saline or venom administration IM and repeated every hour $(5 \mathrm{~mL} / \mathrm{kg})$ for the next five hours. Twentyfour hours after administration, the mice were killed by decapitation. Blood was subjected to hematic biometry while the hearts and skeletal muscles were quickly removed and fixed in 10\% formaldehyde to determine cellular damage by histology (10).

\section{Statistical Analysis}

Data are expressed as means \pm SE (standard error) and the values of all parameters were analyzed by using a one-way analysis of variance followed by the Student-Newman-Keuls test. A value of $p<0.05$ was considered statistically significant.

\section{RESULTS AND DISCUSSION}

Jamapa is located in the center of the state of
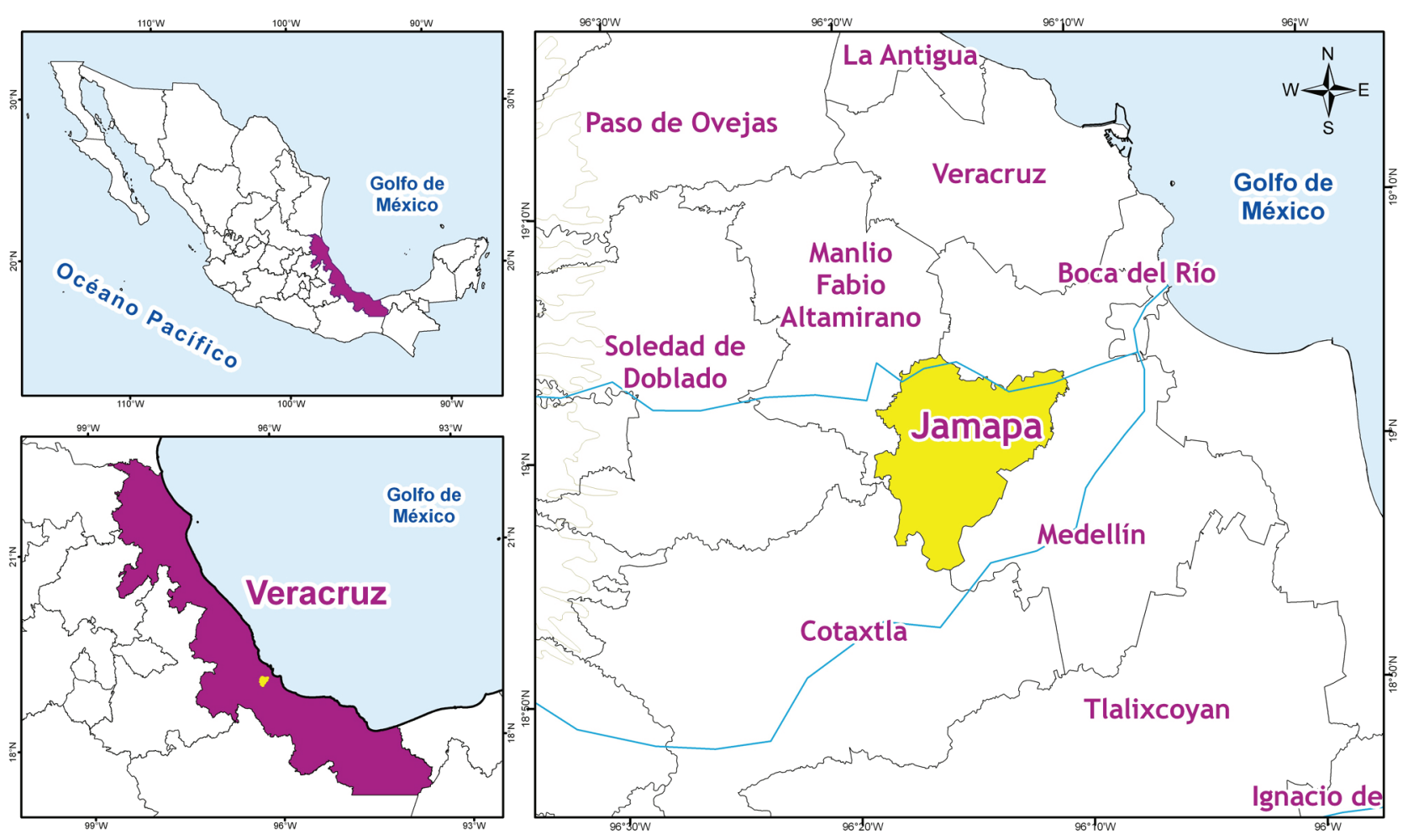

Figure 2. Geographic location of Jamapa in the Mexican state of Veracruz. 
Veracruz, coordinates $19^{\circ} 03^{\prime}$ latitude north and $96^{\circ} 14^{\prime}$ latitude west. Its altitude is 57 meters above sea level. The map of the location can be seen in Figure 2. All the interviews of the ethnobotanical study were realized in this zone; $60 \%$ of the respondents were adult females and $40 \%$ adult males. This is in accordance with the national census, which indicates similar percentages for each gender in this town (11). Of all interviewees, $62 \%$ had intimate knowledge of the plant $(4 \%$ local healers, $12 \%$ merchants who trade with the plant, and $46 \%$ who had taken the plant as a cure), while $35 \%$ knew about the plant but had never used it and 3\% did not know of its existence.

Figure 3 shows the different illnesses in which the plant is employed and its frequency of use. Even though the usage of the plant has been diversified, its main purpose is still to treat the effects of venoms of animals including snakes, spiders, scorpions, toads, bees and wasps (3). Other uses are as an anti-inflammatory or painkilling agent, properties that may also be coadjuvant, by making a snakebite less painful and less swollen, effects due to the action of the plant against the tissue necrosis and the damage induced by the fangs themselves $(12,13)$. Less common applications of this plant are in the treatment of such chronic diseases as diabetes and cancer; furthermore, an immune modulator effect has been reported (14). With the information gathered an ethnobotanical table of $R$. aculeata was created (Table 1), where it

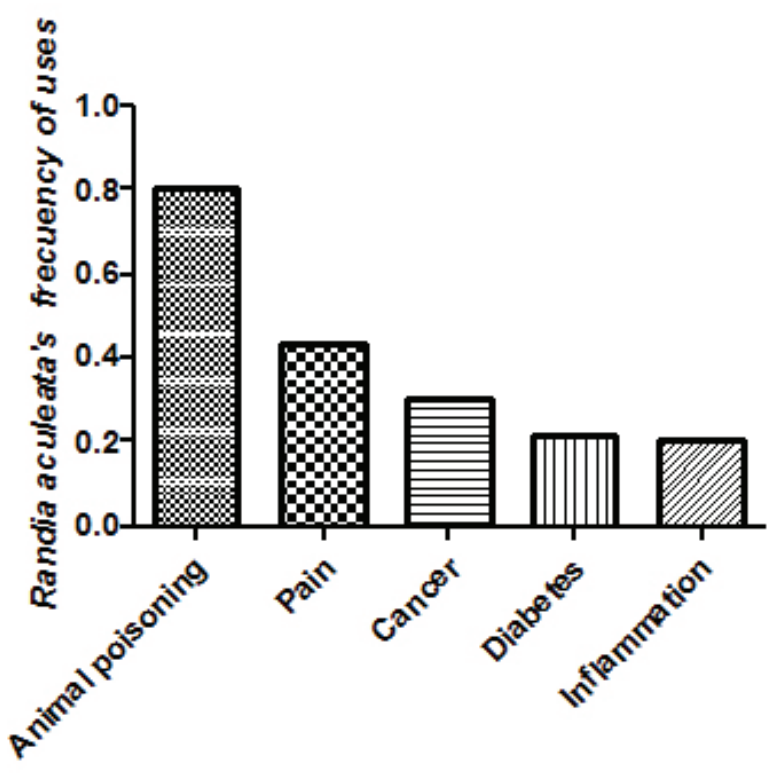

Figure 3. Randia aculeata's frequency of use in the region of Jamapa, Veracruz, Mexico. can be seen that "crucetillo" or "crucetillo macho" are the most popular names (crucetillo due to the cross shaped flower of the species) of the plant. All of the interviewees made the preparation of the plant by using only the fruit, while only $6 \%$ did not report including the peel.

The reported method of use was always the same: seven pieces of fruit were chopped up and left immersed in $1 \mathrm{~L}$ of sherry wine, beer or cane liquor for one week. None of the interviewees mixed this fruit with other vegetable species. The method of administration was reported as oral or topical, depending on the case. The plant is not only used against $B$. asper (nauyaca) and Crotalus sp. (rattlesnake) venoms, but also against Micrurus sp., Hymenoepimecis sp., Apis sp., Latrodectus sp., and Centruroides sp. It is even employed as a remedy for pets that accidentally bite Bufo toads. Thus, future investigation is needed to assess the effectiveness of this plant against different venoms.

Regarding the in vitro study, the results obtained for the $\mathrm{LD}_{50}$ were $2.5 \mathrm{mg} / \mathrm{kg}$ for $B$. asper and $10 \mathrm{mg} / \mathrm{kg}$ for $C$. simus. These data are consistent with the toxicological findings already reported for other species of snakes (15).

The groups treated with venoms (B. asper or C. simus) presented a mortality rate of $37.5 \%$. The groups that received $R$. aculeata and venoms showed $12.5 \%$ mortality. There were no deaths in the control group or among the animals treated with $R$. aculeata only.

Figure 4 shows the effects of the venom and $R$. aculeata on the parameters of red blood cells. The decrease in these cells after experimental application of snake venom is consistent with the hematological findings from Floriano et al. (16), who observed similar results in rats. We also found in our model a decrease in microhematocrits (Figure 4-A) and in the total hemoglobin (Figure $4-\mathrm{B}$ ), effects commonly associated with the loss of red blood cells. Figure 3 - A shows partial protection in relation to these parameters resulting from the administration of $R$. aculeata, possibly due to an inhibitor effect on the proteolytic enzymes which cause the hemotoxic effects on both of the snake venoms evaluated (17).

As for leukocytes (Table 2), in our model no significant changes were found in the experimental groups. On the other hand, only B. asper venom significantly diminished the number of platelets, 
Table 1. Information on Randia aculeata and its use gathered in the municipality of Jamapa, Veracruz, Mexico

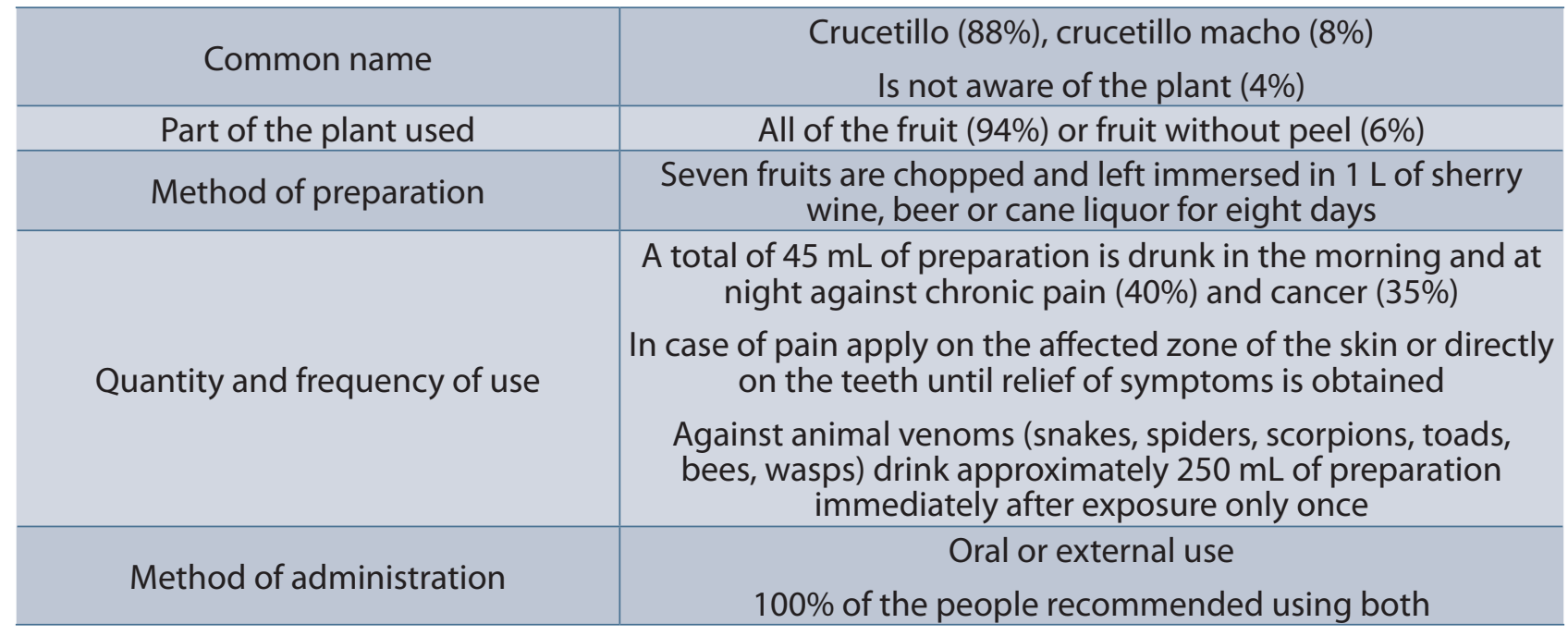
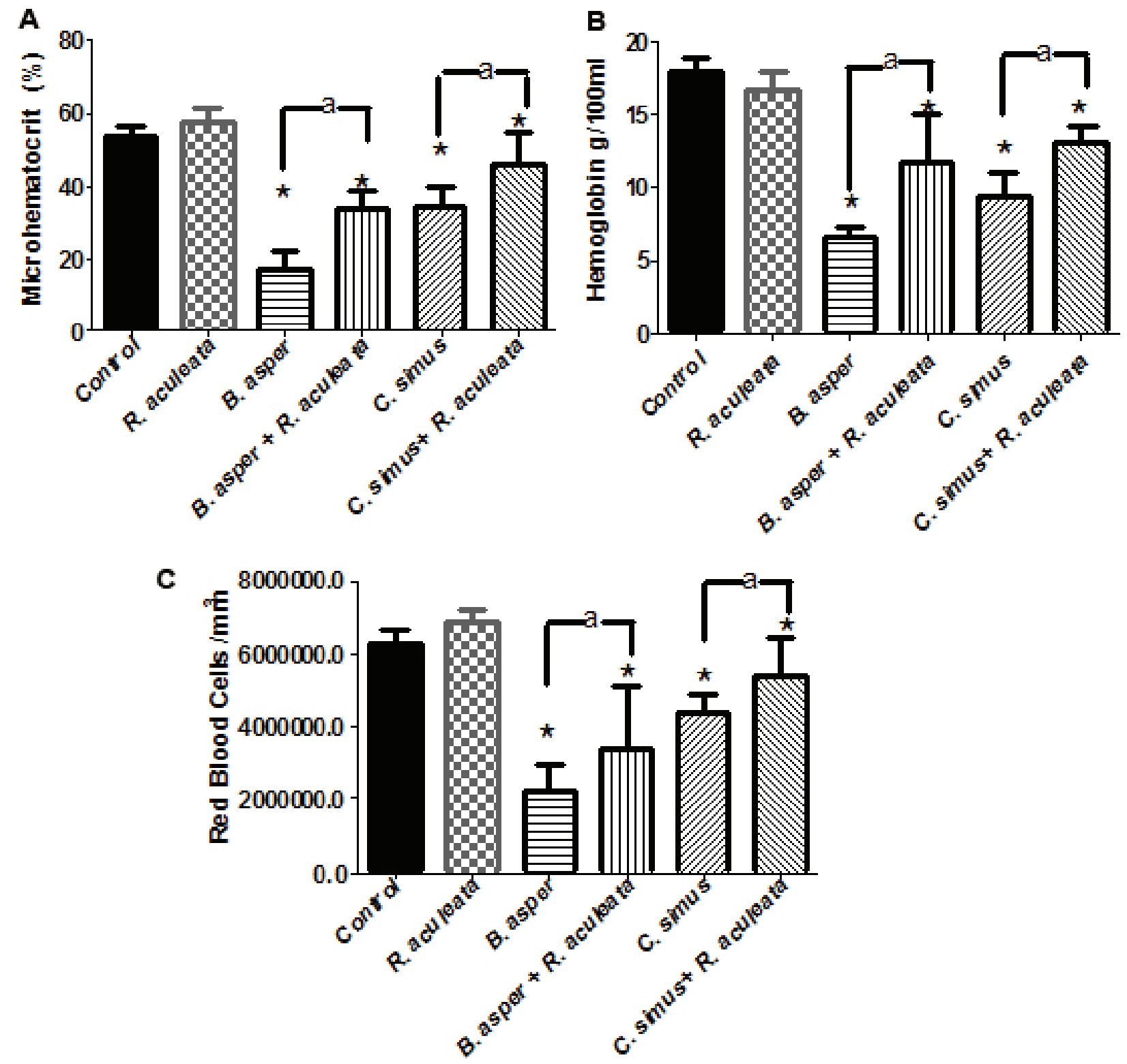

Figure 4. Effect of Randia aculeata administration on (A) microhematocrit, (B) hemoglobin and (C) red blood cells. ${ }^{*} p<0.05$ vs. control group; a $p<0.05$ vs. B. asper and C. simus. 
Table 2. Average and standard deviation of the leukocyte and platelet values by group: data are means \pm SE. ${ }^{*} p<0.05$ vs. control group

\begin{tabular}{c|c|c|c|c|c|c|}
\hline \multirow{2}{*}{ Cells } & \multicolumn{6}{|c|}{ GROUPS } \\
\cline { 2 - 7 } & Control & R. aculeata & B. asper & $\begin{array}{c}\text { B.asper }+R . \\
\text { acuelata }\end{array}$ & C. simus & $\begin{array}{c}\text { C. simus }+R . \\
\text { aculeata }\end{array}$ \\
\hline $\begin{array}{c}\text { Leukocytes/ } \\
\mathrm{mm}^{3}\end{array}$ & $5900 \pm 111$ & $3875 \pm 781$ & $3150 \pm 719$ & $2250 \pm 945$ & $3300 \pm 578$ & $4200 \pm 1116$ \\
\hline Platelets/mm $/ \mathrm{mm}^{3}$ & $61997 \pm 2926$ & $68850 \pm 18069$ & $10745 \pm 1220^{*}$ & $38756 \pm 10368$ & $46470 \pm 12000^{*}$ & $52670 \pm 14116$ \\
\hline
\end{tabular}

a finding similar to what Mendes et al. (18) reported in mice and in other human case reports (19). The current contribution shows that Randia aculeata protects against this event, which is why we infer that one of the plant's effects could be avoiding hemorrhages otherwise caused by snake venom, as has been demonstrated by employing other vegetal species (20-23). It is also possible that this plant can partially neutralize myotoxic effects caused by some snake venoms, which are caused by phospholipase $A_{2}$, metalloproteases and crotoxins $(18,24)$. It has been proven that some plants can neutralize these toxins in vitro $(23,25)$.

Our results showed a partial protective effect on skeletal muscle and myocardium (Figures 5 and 6). When the venom was administered, both these muscle types showed severe necrosis, which was partially inhibited by the administration of $R$. aculeata. As an inflammatory infiltrate, the plant's administration could be used as a complement to therapies that currently do not neutralize the degradation of tissue caused by snakebites (26).

\section{CONCLUSIONS}

In conclusion, the results of the present study show that Randia aculeata causes a decrease in both the microhematocrit (Figure $4-\mathrm{A}$ ) and total hemoglobin (Figure $4-\mathrm{B}$ ), parameters which are often increased in conjunction with the loss of red blood cells that is a characteristic effect of $C$. simus and $B$. asper venoms. This effect could be due to an inhibitor effect on the proteolytic enzymes that cause the hemotoxic effects provoked by
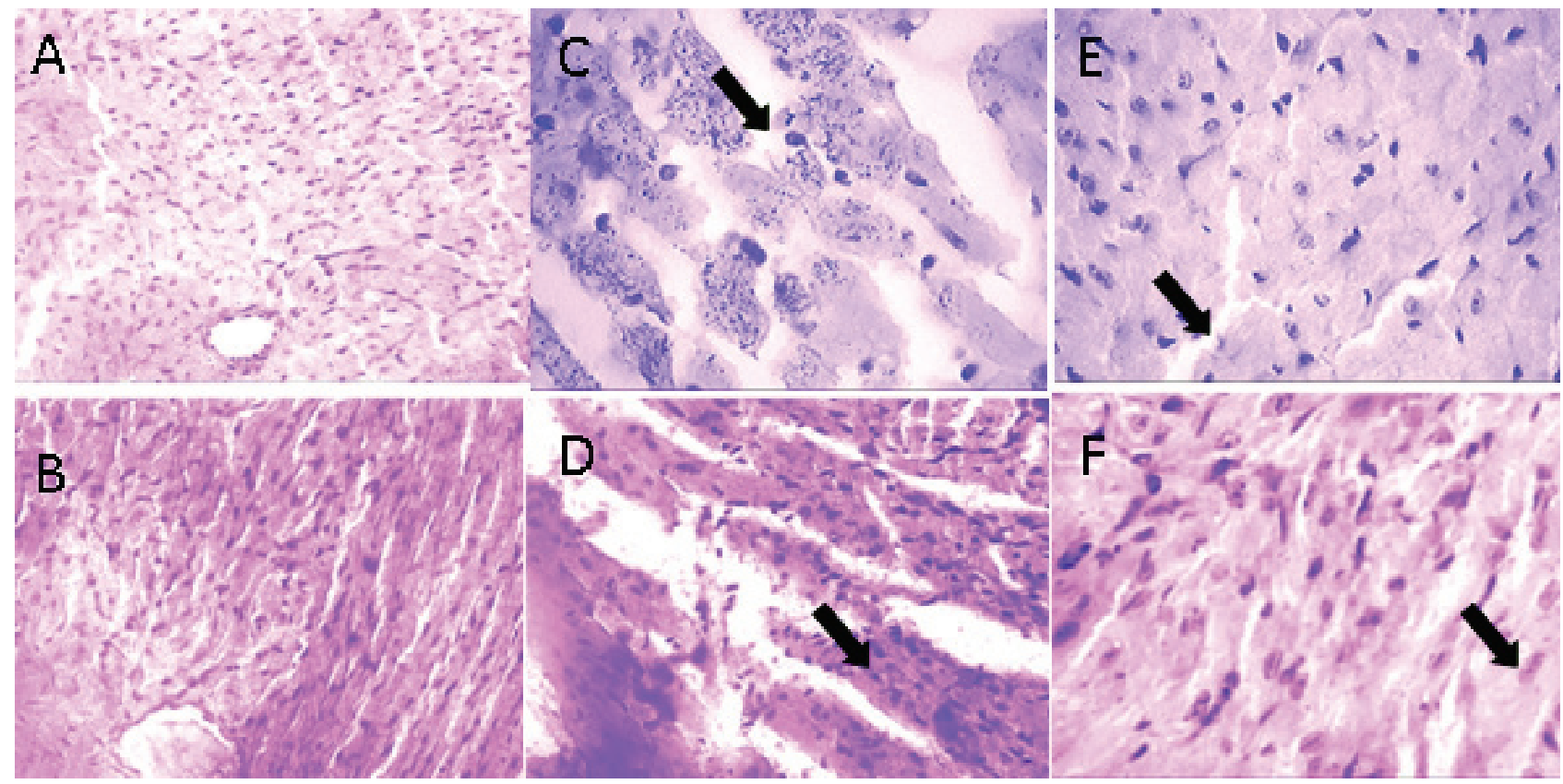

Figure 5. Photomicrographs of heart muscle. (A) Control group, (B) group treated with R. aculeata, (C) B. asper venom, 1 mg. $\mathrm{kg}^{-1}$, (D) C. simus venom $2.5 \mathrm{mg} \cdot \mathrm{kg}^{-1}$, (E) B. asper venom, $1 \mathrm{mg} \cdot \mathrm{kg}^{-1}+R$. aculeata. (F) C. simus venom $2.5 \mathrm{mg} . \mathrm{kg}^{-1}$ plus $R$. aculeata. The tissue was stained by hematoxylin-eosin. Treatment with venoms caused necrosis, hyperchromatic nuclei, and edema (arrows in C and D). Histological alterations were partially ameliorated in groups treated with $R$. aculeata (arrows in $\mathrm{E}$ and $\mathrm{F}$ ). 


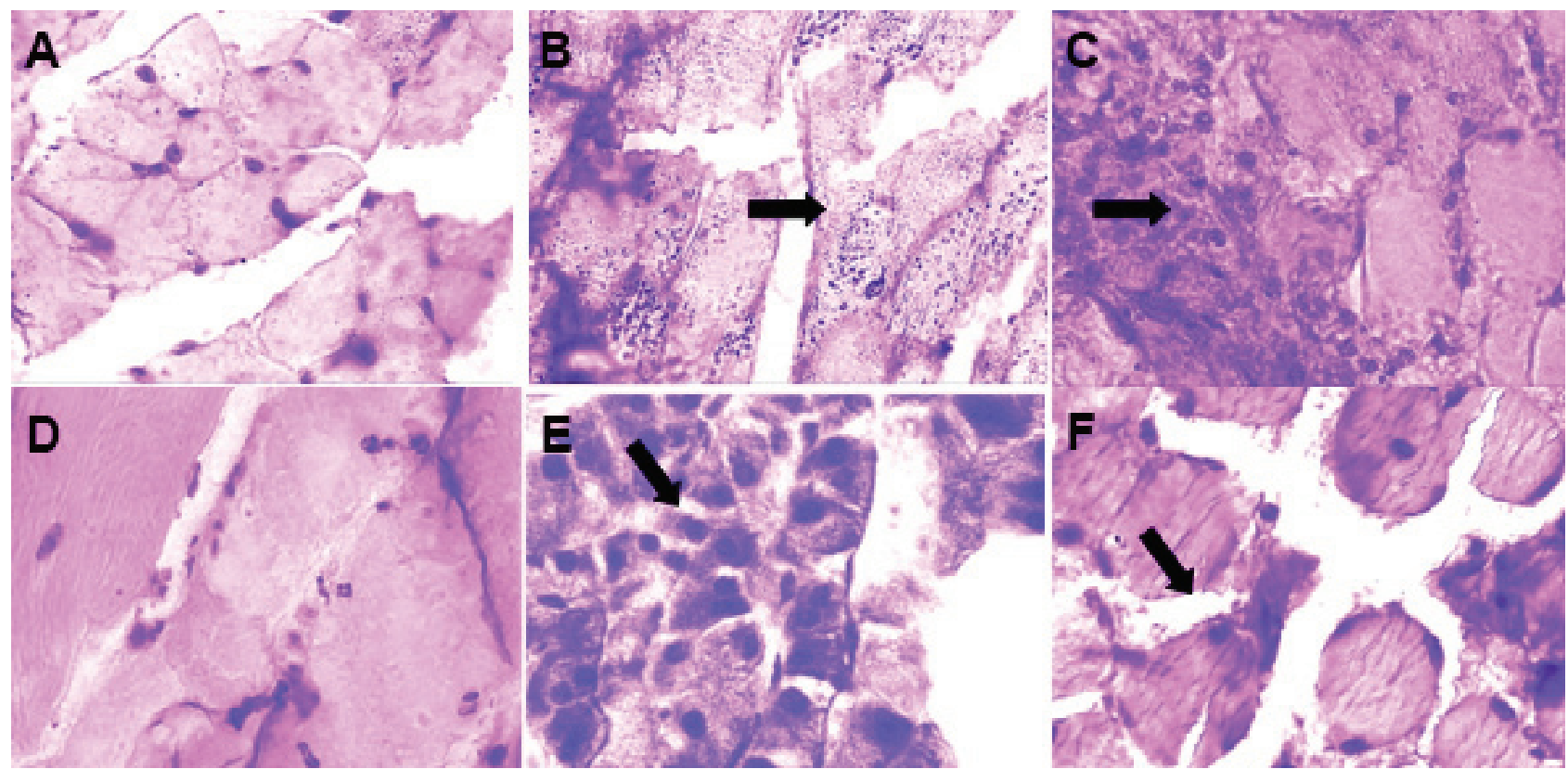

Figure 6. Photomicrographs of skeletal muscle. (A) Control group, (B) group treated with R. aculeata, (C) B. asper venom, $1 \mathrm{mg} \cdot \mathrm{kg}^{-1}$, (D) C. simus venom $2.5 \mathrm{mg} \cdot \mathrm{kg}^{-1}$, (E) B. asper venom, $1 \mathrm{mg} \cdot \mathrm{kg}^{-1}+$ R. aculeata, (F) C. simus venom 2.5 mg.kg-1 plus R. aculeata. The tissue was stained by hematoxylin eosin. Treatment with venoms causes necrosis, edema and abundant inflammatory infiltrate (arrows in C and D). Histological alterations were partially ameliorated in groups treated with R. aculeata (arrows in E and F).

both of the snake venoms evaluated. In this study, Randia aculeata was also shown to protect against the lowering of platelet levels otherwise caused by $B$. asper venom, which could be related to an avoidance of hemorrhaging. Finally, our results show that Randia aculeata produces a partial inhibition of the necrosis found after the administration of snake venom, in skeletal and cardiac muscle (Figures 5 and 6). The popular use of Randia aculeata as an anti-inflammatory agent should be investigated in future studies, given the possibility that this mechanism may protect against tissue damage. This is the first study where the cytoprotective properties of this plant against snake venom have been confirmed in a murine model. Although this mechanism is unknown, the study and isolation of $R$. aculeata's components should be considered as a treatment against snakebites.

\section{ACKNOWLEDGMENTS}

This study was partially supported by SIP-IPN 20110360, EDI, COFFA and CONACyT. Thanks to Abigail Aguilar-Contreras for identifying the plant and to geographer Carmen Alejandra Jimenez-Sanchez for making the location map. We also thank Carlos Castillo Henkel, PhD.

\section{COPYRIGHT}

(C) CEVAP 2012

\section{SUBMISSION STATUS}

Received: March 15, 2012.

Accepted: May 30, 2012.

Abstract published online: June 4, 2012.

Full paper published online: August 31, 2012.

\section{CONFLICTS OF INTEREST}

The authors declare no conflicts of interest.

\section{FINANCIAL SOURCE}

EDI, COFFA and CONACyT provided the financial grants.

\section{ETHICS COMMITTEE APPROVAL}

The present study was approved by the Ethics Committee of the Escuela Superior de MedicinaIPN. All experimental procedures described in the present study are in accordance with the guidelines established by the Secretary of Health in the Seventh Title of the Regulations of the General Law of Health Regarding Health Research and the Mexican Official Standard NOM-062-ZOO-1999, which stipulates technical specifications for production, care, and use of laboratory animals. 


\section{CORRESPONDENCE TO}

María del Carmen Castillo-Hernández, Sección de Estudios de Posgrado e Investigación, Escuela Superior de Medicina, I.P.N., Plan de San Luis y Díaz Mirón, Col. Casco de Sto. Tomás México D.F., 11340, México. Phone: 525729630062827. Email: castillohernandezmc@gmail.com.

\section{REFERENCES}

1. Sotelo-Cruz N. El tratamiento de la mordedura por serpientes. Un enfoque práctico. Rev Mex Pediatr. 1997;64(1):33-9.

2. Reyes-Chilpa R, Gómez-Garibay F, Quijano L, MagosGuerrero GA, Rios T. Preliminary results on the protective effect of (-)-edunol, a pterocarpan from Brongniartia podalyrioides (Leguminosae), against Bothrops atrox venom in mice. J Ethnopharmacol. 1994;42(3):199-203.

3. Ramos-Hernández M, Ávila-Bello CH, Morales Mávil JE. Etnobotánica y ecología de plantas utilizadas por tres Curanderos contra la mordedura de serpiente en la región de Acayucan, Veracruz, México. Bol Soc Bot Mex. 2007;81:89-100.

4. Albalat-Botana A. Culebreros, médicos tradicionales especialistas en serpientes. Agroentorno. 2010;123:32.

5. Hernández CG, Bravo AA. Bites by venomous snakes: epidemiologic panorama in Mexico. Salud Publica Mex. 2009;51(2):95-6.

6. Vázquez-Ramírez MA, Meléndez-Camargo ME, Arreguín-Sánchez ML. Estudio etnobotánico de Selaginella lepidophylla (Hook. Et Grev.) Spring (Selaginellaceae-Pteridophyta) en San José XicohténcatlI Municipio de Huamantla, Tlaxcala, México. Polibotánica. 2005;19:105-15.

7. Méndez Ventura LM, Hernández Medel MR. Toxicity evaluation of Randia monantha Benth fruit. Rev Med UV. 2009;9(Suppl 1):42-5.

8. Bradford MM. A rapid and sensitive method for the quantitation of microgram quantities of protein utilizing the principle of protein-dye binding. Anal Biochem. 1976;72:248-54.

9. Lorke D. A new approach to practical acute toxicity testing. Arch Toxicol. 1983;54(4):275-87.

10. Brown BA. Hematology: Principles and procedures. 3rd ed. Philadelphia: Lea \& Febiger; 1980.

11. E-Local [Internet]. SEGOB [updated 2011 Sep 01; cited 2012 Mar 02]. Available

http://www.e-local.gob.mx/work/templates/enciclo/ veracruz/municipios/30090a.htm

12. Ghosh D, Thejomoorthy P, Veluchamy. Antiinflammatory and analgesic activities of oleanolic acid 3-/3- Glucoside (RDG-1) from Randia dumetorum (Rubiaceae). Indian J Pharmacol. 1983;(4):331-340.

13. Ruppelt BM, Pereira EF, Goncalves LC, Pereira NA. Pharmacological screening of plants recommended by folk medicine as anti-snake venom - I. Analgesic and anti-inflammatory activities. Mem Inst Oswaldo Cruz. 1991;86(Suppl 2):203-5.
14. Satpute KL, Jadhav MM , Karodi RS, Katare YS, Patil MJ, Rukhsana Rub AR. Immunomodulatory activity of fruits of Randia dumetorum Lamk. J Pharmacognosy Phytother. 2009;1(3):36-40.

15. de Roodt AR, Estévez-Ramirez J, Paniagua-Solis JF, Litwin S, Carvajal-Saucedo A, Dolab JA, et al. Toxicity of venoms from snakes of medical importance in Mexico. Gac Med Mex. 2005;141(1):13-21.

16. Floriano RS, Nogueira RM, Sakate M, Laposy CB, da Motta YP, Sangiorgio F, et al. Effect of Mikania glomerata (Asteraceae) leaf extract combined with anti-venom serum on experimental Crotalus durissus (Squamata: Viperidae) envenomation in rats. Rev Biol Trop. 2009;57(4):929-37.

17. Juliá Zertuche J. Mexican reptiles of significance for public health and their geographic distribution. Salud Publica Mex. 1981;23(4):329-43.

18. Mendes MM, Oliveira CF, Lopes DS, Vale LH, Alcantara TM, Izidoro LF, et al. Anti-snake venom properties of Schizolobium parahyba (Caesalpinoideae) aqueous leaves extract. Phytother Res. 2008;22(7):859-66.

19. Sotelo-Cruz N. Rattlesnake bite poisoning, health damage and treatment in children. Gac Med Mex. 2003;139(4):317-24.

20. Castro O, Gutiérrez JM, Barrios M, Castro I, Romero M, Umaña E. Neutralization of the hemorrhagic effect induced by Bothrops asper (Serpentes: Viperidae) venom with tropical plant extracts. Rev Biol Trop. 1999;47(3):605-16.

21. Nuñez V, Otero R, Barona J, Saldarriaga M, Osorio RG, Fonnegra R, et al. Neutralization of the edemaforming, defibrinating and coagulant effects of Bothrops asper venom by extracts of plants used by healers in Colombia. Braz J Med Biol Res. 2004;37(7):969-77.

22. Rodrigues VM, Soares AM, Guerra-Sa R, Rodrigues V, Fontes MR, Giglio JR. Structural and functional characterization of neuwiedase, a nonhemorrhagic fibrin(ogen)olytic metalloprotease from Bothrops neuwiedi snake venom. Arch Biochem Biophys. 2000;381(2):213-24.

23. Vale LH, Mendes MM, Hamaguchi A, Soares AM, Rodrigues VM, Homsi-Brandeburgo MI. Neutralization of pharmacological and toxic activities of Bothrops snake venoms by Schizolobium parahyba (Fabaceae) aqueous extract and its fractions. Basic Clin Pharmacol Toxicol. 2008;103(1):104-7.

24. Otero R, Fonnegra R, Jiménez SL, Núnez V, Evans N, Alzate SP, et al. Snakebites and ethnobotany in the northwest region of Colombia: Part I: traditional use of plants. J Ethnopharmacol. 2000;71(3):493-504.

25. Maiorano VA, Marcussi S, Daher MA, Oliveira CZ, Couto LB, Gomes OA, et al. Antiophidian properties of the aqueous extract of Mikania glomerata. J of Ethnopharmacol. 2005;102(3):364-70.

26. Rucavado A, Escalante T, Gutiérrez JM. Effect of the metalloproteinase inhibitor in the systemic toxicity induced by Bothrops asper snake venom: understanding the role of metalloproteinases in envenomation. Toxicon 2004;43(4):417-24. 